\title{
Obesidade nos Corpos das Mulheres e os Olhares sobre os Discursos Medicalizantes
}

\author{
Rogério José de Almeida \\ Orientador: Prof. Dr. Lourdes Maria Bandeira \\ Curso: Doutorado em Sociologia \\ Data da Defesa: 30.04.2013
}

\begin{abstract}
A presente pesquisa tem por objetivo analisar os impactos e/ou influência que os discursos médico-científico e cultural sexista exercem sobre a perspectiva que mulheres obesas e ex-obesas têm em relação à interseção entre a exclusão e inclusão dos corpos na sociedade. O foco analítico para a compreensão do fenômeno se concentra no olhar das mulheres, delimitado por três dimensões do fenômeno: olhar social normativo que exclui, olhar individual subjetivo que auto exclui e olhar individual subjetivo que auto inclui. Identificou-se que tais discursos não valorizam os corpos diferentes, o que repercute sobremaneira nas vivências cotidianas das mulheres obesas e ex-obesas que veem e sentem as consequências de possuir um estigma. $\mathrm{O}$ discurso médico-científico foi apontado como um grande legitimador da difusão de práticas medicalizantes sobre a obesidade e a magreza, como é o caso da cirurgia de redução de estômago. Esses saberes médicos são amplamente divulgados pela mídia e reproduzidos culturalmente sem uma crítica. Considera-se, portanto, que o discurso médico-científico colabora para uma sociedade mais saudável e para a promoção de saúde, mas também é preciso enxergar os potenciais iatrogênicos que causam consequências drásticas nas relações sociais. A relação obesidade e magreza é emblemática nesse sentido, pois a confluência desse discurso com uma cultura sexista engendra práticas divulgadas sem uma crítica, transformando a medicalização da vida e, por consequência, as intervenções médicas em uma legítima panaceia. As conclusões apontam para a necessidade de uma superação epistemológica e prática das ciências médicas.
\end{abstract}

Palavras-chave: Exclusão, Medicina, Mulheres, Obesidade. 